\title{
Early Ordovician Orthide Brachiopods from Mount Arrowsmith, Northwestern New South Wales, Australia
}

\author{
JOHN R. PATERSON* AND GLENN A. BROCK \\ Centre for Ecostratigraphy and Palaeobiology, \\ Department of Earth and Planetary Sciences, Macquarie University NSW 2109, Australia \\ agnostid@hotmail.com.Glenn.Brock@mq.edu.au
}

\begin{abstract}
Two new late Early Ordovician orthide brachiopods, Celsiorthis bulancis n.gen. and n.sp. and Alocorthis psygmatelos n.gen. and n.sp., are described from the Tabita and Pingbilly formations at Mount Arrowsmith, northwestern New South Wales. The associated conodont assemblage from the succession at Mount Arrowsmith indicates a late Bendigonian to Chewtonian age for the brachiopod bearing horizons.
\end{abstract}

Paterson, John R., \& Glenn A. Brock, 2003. Early Ordovician orthide brachiopods from Mount Arrowsmith, northwestern New South Wales, Australia. Records of the Australian Museum 55(2): 221-230.

In a global review of Ordovician brachiopod distribution, Jaanusson (1973) was so frustrated by the lack of data from Australia that he used the term "terra incognita" to describe the major lacuna in knowledge concerning the occurrence of taxa from austral waters. Whilst Percival (in Webby et al., 2000) indicated this situation has improved significantly, especially for Late Ordovician faunas from Tasmania (Laurie, 1991a,b) and New South Wales (Percival, 1979a,b, 1991; Percival et al., 2001), knowledge of Early and Middle Ordovician brachiopod faunas from Australia remains deficient.

The oldest known formally described Ordovician brachiopod fauna from Australia was recorded by Laurie (1987) from the Lancefieldian Digger Island Formation in Victoria. The fauna consists of two orthid species, Finkelnburgia lindneri Laurie and Archaeorthis waratahensis Laurie.

Prendergast (1935) described eleven brachiopod species, including the orthid Spanodonta hoskingiae, from the Gap Creek Formation of the Canning Basin, Western Australia, and indicated a Late Palaeozoic (Permo-Carboniferous) age for the fauna. The Gap Creek Formation is now known to be late Bendigonian (Be3-Be4) in age (Laurie, 1997). Laurie (1997) also described the orthids ?Pseudomimella

* author for correspondence sp., ?Oligorthis sp., Tritoechia sp., and Tinopena shergoldi from the Gap Creek Formation.

Brown (1948) described two clitambonitoid and one porambonitoid species from the Lower Ordovician (Lancefieldian-Castlemanian-see Laurie, 1991a,b) Florentine Valley Formation of southern Tasmania. Laurie (1980) later redescribed Tritoechia lewisi and recorded several new orthoid and clitambonitoid species from the Florentine Valley Formation and overlying Karmberg Limestone. The species Brown (1948) described as ?T. careyi was tentatively referred to Nanorthis carinata by Laurie (1987). The taxon documented as Orthis lenticularis Wahlenberg by Etheridge (1904, pl. 10, figs. 5-9) was also placed in synonymy with $N$. carinata by Laurie (1987). Laurie (1991a) developed a detailed biostratigraphic scheme for the Ordovician of Tasmania based on twenty brachiopod assemblages. In his comprehensive study of the Ordovician and Early Silurian articulate brachiopods of Tasmania, Laurie (1991b) recorded six Early Ordovician brachiopod assemblages, ranging in age from the Lancefieldian to Chewtonian. These six brachiopod assemblages extend from the Pontoon Hill Siltstone Member of the Florentine Valley Formation through to the lower parts of the Karmberg Limestone.

www.amonline.net.au/pdf/publications/1384_complete.pdf 


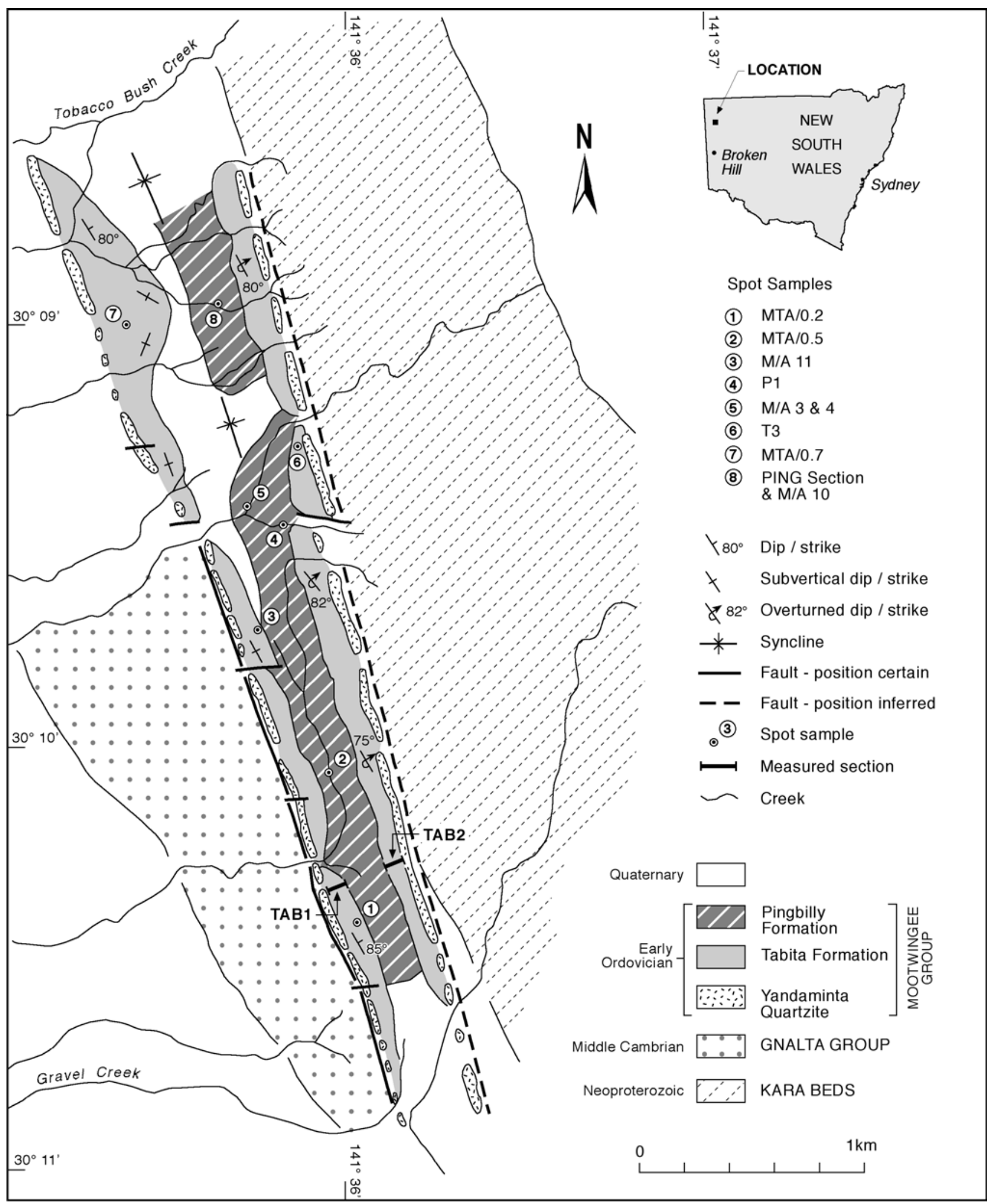

Fig. 1. Geological map of the southwest portion of the Mount Arrowsmith Inlier, northwestern New South Wales. All measured stratigraphic sections and spot localities are shown.

The focus of this paper is to describe two new Early Ordovician orthide brachiopods, apparently endemic to the Mount Arrowsmith region (Gnalta Shelf) of northwestern New South Wales (Fig. 1), and thereby add significant new data on the early evolution and distribution of the Orthida in Australia.

\section{Locality, stratigraphy and age}

Mount Arrowsmith is situated in the northwestern corner of New South Wales (Fig. 1), approximately $80 \mathrm{~km} \mathrm{SSW}$ of Tibooburra and $200 \mathrm{~km}$ north of Broken Hill. The Proterozoic-Palaeozoic inlier at Mount Arrowsmith is one of several protruding through the Mesozoic sediment 
blanket in far northwest New South Wales, forming part of the Wonominta Block (Mills, 1992). Sediments of the Mount Arrowsmith inlier consist of the Neoproterozoic Kara Beds and Mount Arrowsmith Volcanics, Middle Cambrian Gnalta Group, and the Lower Ordovician Mootwingee Group (Fig. 1). The metasediments of the Kara Beds and the intercalated basic-intermediate Mount Arrowsmith Volcanics are latest Neoproterozoic $(586 \pm 7 \mathrm{Ma})$, determined from Zircon U$\mathrm{Pb}$ SHRIMP data from the Mount Arrowsmith Volcanics in the Mount Wright area (Crawford et al., 1997). Sediments of the Middle Cambrian Gnalta Group unconformably overlie the Neoproterozoic Kara Beds, and are subdivided into three units: the Pincally Formation (lowest), Wydjah Formation, and the Wyarra Shale (highest). Brock \& Percival (2000) suggested an early Middle Cambrian (Ordian-Early Templetonian) age for the succession based on lingulate brachiopods, molluscs and other small shelly fossils.

The Lower Ordovician Mootwingee Group sediments unconformably overlie the Middle Cambrian Gnalta Group. This unconformity probably corresponds to the Delamerian Orogeny, which began during the latest Middle Cambrian and continued into the Early Ordovician (Webby, 1978; Mills, 1992). In terms of palaeogeographic setting, the sediments of the Mootwingee Group were deposited on the Gnalta Shelf near the palaeocontinental margin at the eastern extremity of the Larapintine Sea, a major epicratonic seaway linking cratonic basins such as the Canning, Amadeus, Georgina and Warburton basins with the palaeo-oceans to the east and west of Australia (see Webby et al., 2000, fig. 6).

The Mootwingee Group is subdivided into three distinct units: the Yandaminta Quartzite (lowest), Tabita Formation, and Pingbilly Formation (highest). The Lower Ordovician succession is exposed within a tight overturned syncline 11 $\mathrm{km}$ in length, plunging in a SSE direction. The syncline is separated into northern and southern outcrop tracts by flatlying Mesozoic and Quaternary sediments that cover its central portion. This study focussed mainly on the southern portion of the syncline (Fig. 1) where material was recovered from measured stratigraphic sections through the Tabita Formation (TAB 1: $\left.30^{\circ} 10^{\prime} 20^{\prime \prime} \mathrm{S} 141^{\circ} 35^{\prime} 56^{\prime \prime} \mathrm{E}\right)$ and the Pingbilly Formation (PING: $30^{\circ} 08^{\prime} 57^{\prime \prime S} 141^{\circ} 35^{\prime} 38^{\prime \prime E}$ ), as well as isolated spot samples (including some from the northern part of the syncline).

Specimens of both Celsiorthis bulancis n.gen. and n.sp. and Alocorthis psygmatelos $\mathrm{n}$.gen. and n.sp. are preserved as internal and external moulds within the siltstones and coquinites of the Tabita Formation. Associated biota include dasyclad algae, gastropods, bivalves, cephalopods, trilobites, echinoderms, conodonts, trace fossils and numerous problematic forms (Paterson, 2001a,b, 2002, in press). Alocorthis psygmatelos has a relatively narrow stratigraphic range in the Tabita Formation with the first recorded occurrence of the taxon at $40 \mathrm{~m}$ above the base of the TAB 1 section and the last recorded occurrence at $60 \mathrm{~m}$ above the base of the section (Fig. 2). Celsiorthis bulancis is the dominant brachiopod taxon in the section and has a long stratigraphic range extending through most of the Tabita and Pingbilly formations (Fig. 2). The shells in the quartz siltstones and coquinites of the Tabita Formation are often disarticulated but unbroken and tend to be oriented parallel to bedding. The brachiopod and bivalve shells are often preserved in a hydrodynamically stable convex-up position. The orientation of fossil allochems and the occasional presence of imbrication structures in quartz grains within the siltstones suggest the presence of traction currents. These palaeontological and sedimentological data indicate that the Tabita Formation was deposited in a relatively low energy, well oxygenated, shallow marine, inner shelf environment.

The Pingbilly Formation, of approximately $70 \mathrm{~m}$ maximum thickness, is generally poorly outcropping, but where exposed is dominated by mudstones composed of well sorted, fine, subangular quartz grains with minor grains of muscovite and biotite. The mudstone hosts subangular to rounded lithic clasts ranging in diameter from $0.5-40 \mathrm{~mm}$. The Pingbilly Formation was also probably deposited in a shallow marine environment, possibly in slightly deeper water than the underlying sediments of the Tabita Formation, but the presence of lithic clasts indicates sporadic terrestrial influence.

Conodonts from the Mount Arrowsmith area are largely endemic and lack zonal index taxa making precise age determination and correlation difficult (Zhen et al., 2003). The conodont assemblage described by Zhen et al. (2003), is indicative of the Oepikodus evae conodont Zone from the North Atlantic zonal scheme, or the andinus-aranda zones of the North American Midcontinent succession. This is equivalent to a late Bendigonian to Chewtonian age for the Tabita Formation, based on the Australian Stage scale (Webby, 1998).

\section{Systematic palaeontology}

Type specimens are held in the Australian Museum Palaeontology type collection (AM); museum numbers are given in figure captions and are prefixed F. Higher level systematics follows Williams et al. (1996).

\section{Phylum Brachiopoda Duméril, 1806}

Subphylum Rhynchonelliformea Williams, Carlson, Brunton, Holmer \& Popov, 1996

\section{Class Rhynchonellata Williams, Carlson, Brunton,} Holmer \& Popov, 1996

Order Orthida Schuchert \& Cooper, 1932

Suborder Orthidina Schuchert \& Cooper, 1932

Superfamily Orthoidea Woodward, 1852

Family Orthidae Woodward, 1852

\section{Celsiorthis n.gen.}

Type species. Celsiorthis bulancis n.gen. and n.sp.

Etymology. Latin, m., celsus, high, upright; referring to the high, steeply apsacline to catacline ventral valve interarea.

Diagnosis. Shell ventribiconvex. Ventral valve interarea wide, high, steeply apsacline to catacline. Finely costellate becoming ramicostellate anteriorly, with costellae arising mainly by bifurcation (number of costellae ranges from 80 90 at anterior margin). Ventral valve with large dental plates and bilobed muscle field. Dorsal valve with broad, welldeveloped notothyrial platform occupied by ridge-like cardinal process. Brachiophores tusk-like with thick bases, weakly divergent $\left(40-60^{\circ}\right)$. Dental sockets large. Fulcral plates absent. 


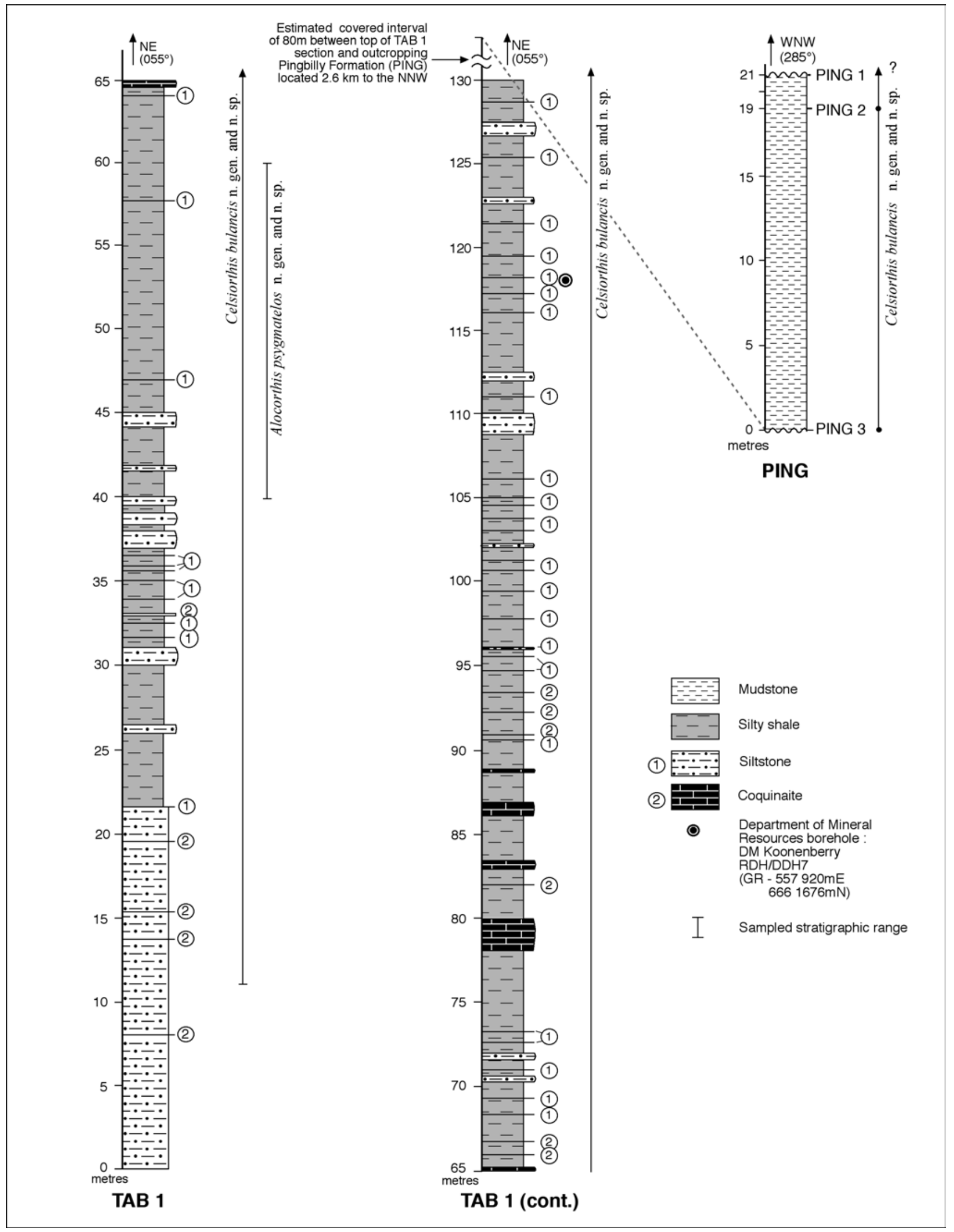

Fig. 2. Stratigraphic ranges of Celsiorthis bulancis n.gen. and n.sp. and Alocorthis psygmatelos n.gen. and n.sp. in the Tabita Formation (TAB 1 section) and Pingbilly Formation (PING section). First outcrop of the PING section is located $2.6 \mathrm{~km}$ NNW from the top of the TAB 1 section (see Fig. 1). The base and top of the Pingbilly Formation are undefined due to poor outcrop caused by alluvial cover. 


\section{Celsiorthis bulancis n.gen. and n.sp.}

Fig. 3A-N, Table 1

Type material. HoLOTYPE: AM F120718, ventral valve (Fig. 3L-N). PARATYPES: AM F120710, dorsal valve (Fig. 3A,B); AM F120711, dorsal valve (Fig. 3C); AM F120712, complete shell (Fig. 3D-F); AM F120713, ventral valve (Fig. 3G); AM F120714, ventral valve (Fig. 3H); AM F120715, ventral valve (Fig. 3I); AM F120716, ventral valve (Fig. 3J); AM F120717, ventral valve (Fig. 3K).

Type locality. Tabita Formation, TAB1 section, $30 \mathrm{~m}$ above base of section (Figs. 1, 2).

Etymology. Latin $b u$, prefix meaning large, and lancis, plate; referring to the large dental plates in the ventral valve.

Diagnosis. As for genus by monotypy.

Description. Exterior: ventribiconvex, subquadrate in outline. Ventral valve moderately and uniformly convex with slightly swollen umbo; hinge width approximately 90 95\% maximum valve width. Ventral interarea wide, high, flat, steeply apsacline to catacline. Delthyrium open. Dorsal valve moderately convex with shallow sulcus occupying median part of valve; maximum length about $60 \%$ of maximum width. Dorsal interarea low, anacline, with open notothyrium; hinge line mainly straight, but slightly deflected posteriorly in the posteromedian region. Commissure rectimarginate.

Shell finely costellate, becoming ramicostellate anteriorly; ribs low and rounded, becoming wider at anterior margin. Costae in umbonal area range between 25 and 35 . Costellae arise principally by bifurcation and number 80 90 along the anterior margin in adult shells. Fine, closely spaced concentric filae occur between costellae in larger specimens.

Ventral valve interior: dental plates large, divergent (approximately $20-30^{\circ}$ ), extending forward as raised lateral muscle bounding ridges. Muscle field large, well impressed, bilobed, about one-third valve length. Diductor scars large, elongate, subparallel; adductors slender, enclosed by diductors, and unbounded anteriorly. Costellae variably impressed around inner margin of shell.

Table 1. Measurements for Celsiorthis bulancis n.gen. and n.sp. Abbreviations: $\mathrm{Mw}=$ maximum width of valve $(\mathrm{mm}) ; \mathrm{Ml}=$ maximum length of valve $(\mathrm{mm})$; Hti = maximum of height of interarea $(\mathrm{mm}) ; \mathrm{Mrc}=$ maximum number of ribs at commissure; $\mathrm{NA}=$ dimension not available.

\begin{tabular}{lllllll}
\hline museum no. & valve & & Mw & Ml & Hti & Mrc \\
\hline AM F120710 & dorsal & paratype & 6 & 3 & NA & NA \\
AM F120711 & dorsal & paratype & 5.5 & 4.5 & NA & NA \\
AM F120712 & dorsal & paratype & 18.5 & 14 & 5.5 & NA \\
AM F120713 & ventral & paratype & 9.5 & 7.5 & NA & NA \\
AM F120714 & ventral & paratype & 5.5 & 5 & NA & NA \\
AM F120715 & ventral & paratype & 7 & 4.5 & NA & NA \\
AM F120716 & ventral & paratype & 7 & 8.5 & NA & NA \\
AM F120717 & ventral & paratype & 9.5 & 8 & NA & 88 \\
AM F120718 & ventral & holotype & 8.5 & 6 & 3 & 86 \\
\hline
\end{tabular}

Dorsal valve interior: cardinalia with broad, welldeveloped notothyrial platform which merges anteriorly with a short, low, broad median ridge. Cardinal process thick, ridge-like, with anterior portion merging with notothyrial platform. Brachiophores short, thick, tusk-like, anterolaterally divergent at $40-60^{\circ}$, grooved along inner faces, with narrow tops, rounded anterior ends, and thick bases joined to the notothyrial platform. Sockets very large with well rounded floors. Fulcral plates absent. Muscle field large, quadripartite, occupying about one-third valve length, bisected longitudinally by low median ridge. Posterior pair of adductors ovate, impressed below notothyrial platform, separated from smaller anterior pair by short transverse extension of the median ridge. Costellae impressed on anterior margin of shell.

Discussion. Celsiorthis bulancis can be distinguished from most other Ordovician members of the Orthidae (see Williams \& Harper, 2000, p. 724-728), such as Orthis Dalman, Orthambonites Pander, Paralenorthis Havlíček, Sulcatorthis Zeng, Sulevorthis Jaanusson \& Bassett, and Trondorthis Neuman in Neuman \& Bruton by its finely costellate to ramicostellate external ornament and steeply anacline to catacline interarea in the ventral valve.

Celsiorthis bulancis is similar to Sivorthis Jaanusson \& Bassett, in particular the type species S. filistera Jaanusson \& Bassett (1993, pl. 7, figs. 1-7), from the Ordovician (Caradoc) of Sweden. Both taxa possess a ventribiconvex shell, a high, wide ventral valve interarea, and have a similar costellate ornament. However, C. bulancis can be distinguished by its nearly flat, steeply apsacline to catacline ventral interarea (Figs. 3D,F,M,N), whereas S. filistera has a weakly apsacline ventral valve interarea. Celsiorthis bulancis is also more finely costellate (80-90 costellae along the anterior margin; Figs. 3L,K) than S. filistera (40-50 costellae at anterior margin). The internal morphology of the ventral valve is very similar in both species; both have a large bilobed or subcordate muscle field bounded by relatively large dental plates (Figs. 3G-J). The interior of the dorsal valve of $C$. bulancis is also similar to $S$. filistera in having a well-developed notothyrial platform supported by a broad median ridge, and a large, quadripartite muscle field in which the posterior muscle scars are larger than the anterior pair (Figs. 3A-C). However, C. bulancis has considerably larger dental sockets, and tusk-like brachiophores with thick bases (Figs. 3A-C), unlike S. filistera which has simple, tabular brachiophores. Other species assigned to Sivorthis by Jaanusson \& Bassett (1993, p. 46) differ greatly from $C$. bulancis, primarily in their coarser ornamentation and cardinalia, and thus do not warrant close comparison.

The genus Sinorthis, based on S. typica, described by Wang (1955) from the Lower Ordovician (Arenig) of south China is also finely costellate, but can be distinguished from C. bulancis by its widely divergent brachiophores and weakly apsacline, relatively small ventral valve interarea. Orthostrophia Hall, is a significantly younger genus and can be distinguished from $C$. bulancis by its coarser ramicostellate ornament, dorsibiconvex to resupinate shell and subtriangular ventral valve muscle scar. 


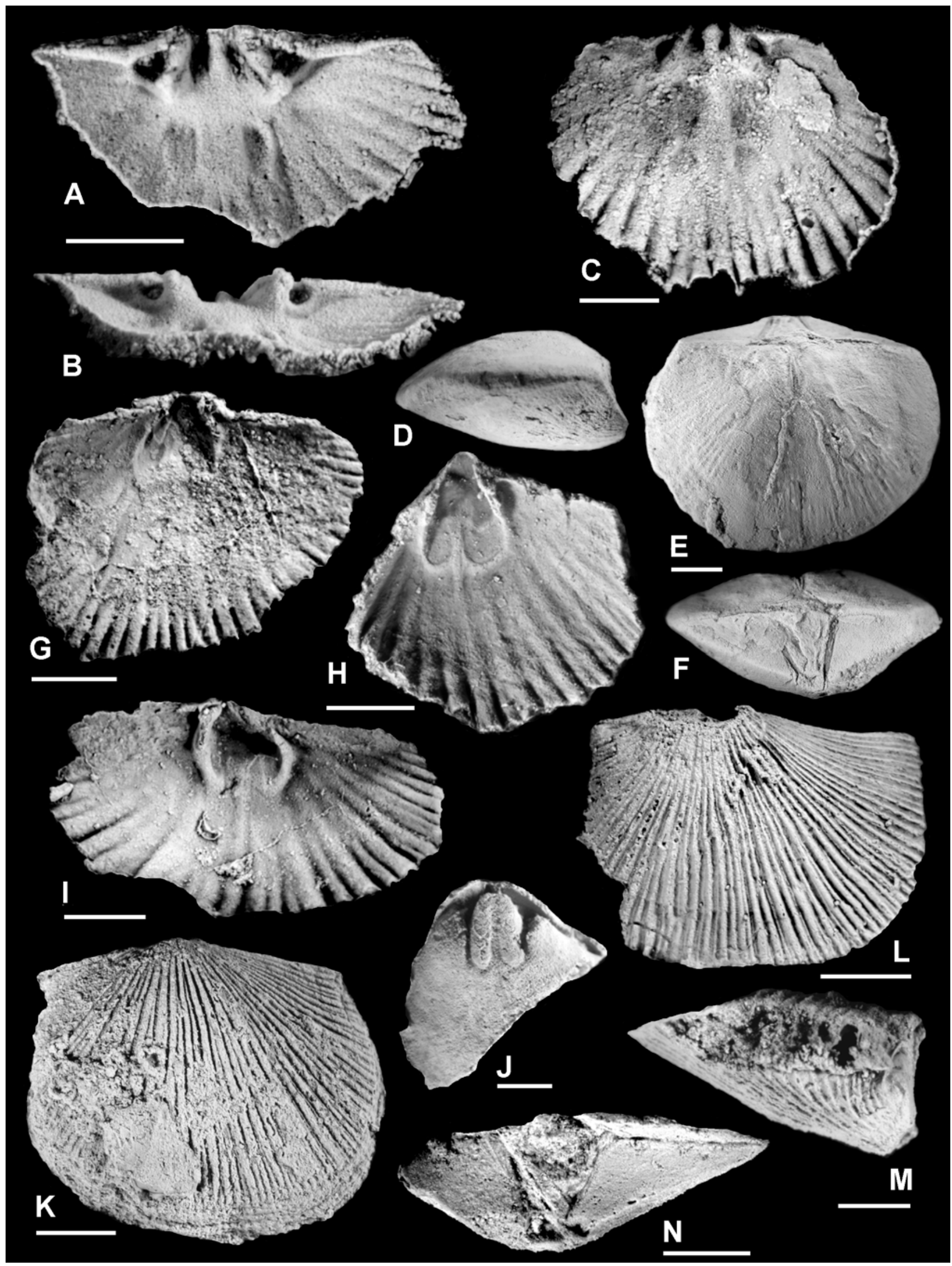

Fig. 3. Celsiorthis bulancis n.gen. and n.sp. $(A, B)$ dorsal valve interior and anterior, locality T3, AM F120710, scale bar $=1.5 \mathrm{~mm} ;(C)$ latex of dorsal valve interior, PING1, AM F120711, scale bar $=1 \mathrm{~mm} ;(D-F)$ lateral, dorsal and posterior views of complete abraded shell, TAB1/20 m, AM F120712, scale bar $=3 \mathrm{~mm} ;(G)$ latex of ventral valve interior, PING1, AM F120713, scale bar $=2.5 \mathrm{~mm} ;(H)$ latex of ventral valve interior, PING1, AM F120714, scale bar $=2 \mathrm{~mm} ;(I)$ latex of ventral valve interior, PING1, AM F120715, 
Family Nanorthidae Havlíček, 1977

\section{Alocorthis n.gen.}

Type species. Alocorthis psygmatelos n.gen. and n.sp.

Etymology. Greek, f., alokos, meaning furrow; referring to the furrows extending along the dorsal surfaces of the brachiophores.

Diagnosis. Shell transverse, weakly ventribiconvex. Ventral muscle field subtriangular, raised above valve floor and restricted to delthyrial cavity, bounded by short receding dental plates. Notothyrial platform short and very wide, anteriorly elevated above valve floor, supported by broad median ridge. Cardinal process absent. Brachiophores short, widely divergent $\left(100-110^{\circ}\right)$, with furrows extending along dorsal surfaces and with fan-like terminations. Dental sockets simple, subcircular. Fulcral plates absent.

\section{Alocorthis psygmatelos n.gen. and n.sp.}

Fig. 4A-J, Table 2

Type material. HOLOTYPE: AM F120719, dorsal valve (Fig. 4A,B). PARATYPES: AM F120720, dorsal valve (Fig. 4C,D); AM F120721, dorsal valve (Fig. 4E); AM F120722, ventral valve (Fig. 4F,G); AM F120723, ventral valve (Fig. 4H,I); AM F120724, ventral valve (Fig. 4J).

Type locality. Tabita Formation (spot locality MTA/IV/4, northern section of the syncline at $30^{\circ} 06^{\prime} 36^{\prime \prime S} 141^{\circ} 35^{\prime} 05^{\prime \prime} \mathrm{E}$ ).

Etymology. Greek psygma, fan, and telos, end; referring to the fan-like anterior extremities of the brachiophores.

Diagnosis. As for genus by monotypy.

Description. Exterior: poorly preserved in available material, but apparently weakly ventribiconvex, transverse, subquadrate in outline. Ventral valve interarea low and weakly apsacline; delthyrium open; maximum length of ventral valve approximately $70 \%$ maximum width. Dorsal valve interarea anacline; notothyrium open; maximum length of dorsal valve approximately 55\% maximum width. Fine ramicostellate ornament, with ribs arising by bifurcation.

Ventral valve interior: muscle field subtriangular with curved anterior margin, restricted to delthyrial cavity, bounded laterally by short receding dental plates; muscle field slightly raised above valve floor, about one-fifth valve length in larger specimens. Teeth relatively large, simple, deltidiodont. Strap-like vascula media weakly impressed, proximal portions well separated and divergent (Fig. 4I). Ribs impressed on periphery of valve.

Dorsal valve interior: notothyrial platform short and very wide, anteriorly elevated above valve floor, supported by short, wide, very low median ridge. Cardinal process absent. Brachiophores short, robust, with narrow furrows $(\leq 0.25$ $\mathrm{mm}$ in width) situated along dorsal surfaces and fan-like anterior extremities, widely divergent anterolaterally at
Table 2. Measurements for Alocorthis psygmatelos n.gen. and n.sp. Abbreviations: $\mathrm{Mw}=$ maximum width of valve $(\mathrm{mm}) ; \mathrm{Ml}=$ maximum length of valve $(\mathrm{mm})$; Hti = maximum of height of interarea $(\mathrm{mm})$; $\mathrm{Mrc}=$ maximum number of ribs at commissure; $\mathrm{NA}=$ dimension not available.

\begin{tabular}{lllllll}
\hline museum no. & valve & & Mw & Ml & Hti & Mrc \\
\hline AM F120719 & dorsal & holotype & 12 & 6 & NA & NA \\
AM F120720 dorsal & paratype & 10 & 5 & NA & 74 \\
AM F120721 dorsal & paratype & 6 & 5.5 & NA & NA \\
AM F120722 ventral & paratype & 7.5 & 5.5 & NA & NA \\
AM F120723 ventral & paratype & 6.5 & 5.5 & 1.5 & NA \\
AM F120724 ventral & paratype & 5.5 & 6.5 & 2 & NA \\
\hline
\end{tabular}

about $100-110^{\circ}$. Dental sockets simple, subcircular and deep. Fulcral plates absent. Musculature poorly defined; posterior pair large and subcircular, situated on either side of a relatively wide, low median ridge, below the notothyrial platform. Internal ribbing as in ventral valve.

Discussion. The relatively small (Table 2) subquadrate, weakly ventribiconvex, transverse shell, subtriangular ventral valve muscle scar (Figs. 4F-J), presence of a wide notothyrial platform, short, robust, widely divergent brachiophores, and absence of a cardinal process in the dorsal valve (Figs. 4A-E) indicate that Alocorthis psygmatelos could be placed in either the Nanorthidae (Superfamily Orthoidea) or the Eoorthidae (Superfamily Plectorthoidea). As noted by Williams \& Harper (2000, p. 766) the eoorthids differ significantly from other typical plectorthoids in lacking brachiophore supporting structures and fulcral plates. Williams \& Harper (2000) indicate that the eoorthids should be viewed as the link group between the plectorthoids and the orthoids. On balance, Alocorthis probably has more features in common with the Nanorthidae than with the Eoorthidae and we refer this genus, with some hesitation, to the Nanorthidae Havlíček.

Of the genera lacking a cardinal process that are currently assigned to the Nanorthidae (see Williams \& Harper, 2000, p. 742-745), Alocorthis is similar to both Nanorthis Ulrich \& Cooper and Archaeorthis Schuchert \& Cooper. Nanorthis has a similar ornament, shell shape and size range to Alocorthis, but Nanorthis can be discriminated from Alocorthis by its short, blade-like brachiophores and rudimentary notothyrial platform (Laurie, 1980; Williams \& Harper, 2000). The species N. brachymyaria recently described from the Late Tremadoc of Argentina (Benedetto \& Carrasco, 2002, fig. 4) is very similar to Alocorthis in size and external ornament. However, N. brachymyaria can be distinguished from A. psygmatelos by its more acute brachiophore angle, lack of a raised muscle field in the ventral valve and more arched vascula media. It is interesting to note that Benedetto \& Carrasco (2002, fig. 4.11) figure one specimen of $N$. brachymyaria that appears to show brachiophores with narrow furrows along the dorsal surfaces and fan-like terminations which indicate this species may be referable to Alocorthis.

[Fig. 3, caption continued] $\ldots$ scale bar $=1.5 \mathrm{~mm} ;(J)$ ventral valve internal mould, TAB1/25 m, AM F120716, scale bar $=2.5 \mathrm{~mm} ;(K)$ latex of ventral valve exterior, MTA/0.2, AM F120717, scale bar $=2.5 \mathrm{~mm} ;(L-N)$ Holotype, latex of ventral valve exterior (scale bar $=2.5 \mathrm{~mm}$ ), lateral view (scale bar $=1.5 \mathrm{~mm}$ ) and interarea (scale bar $=2 \mathrm{~mm}$ ), TAB1/30 $\mathrm{m}$, AM F120718. 


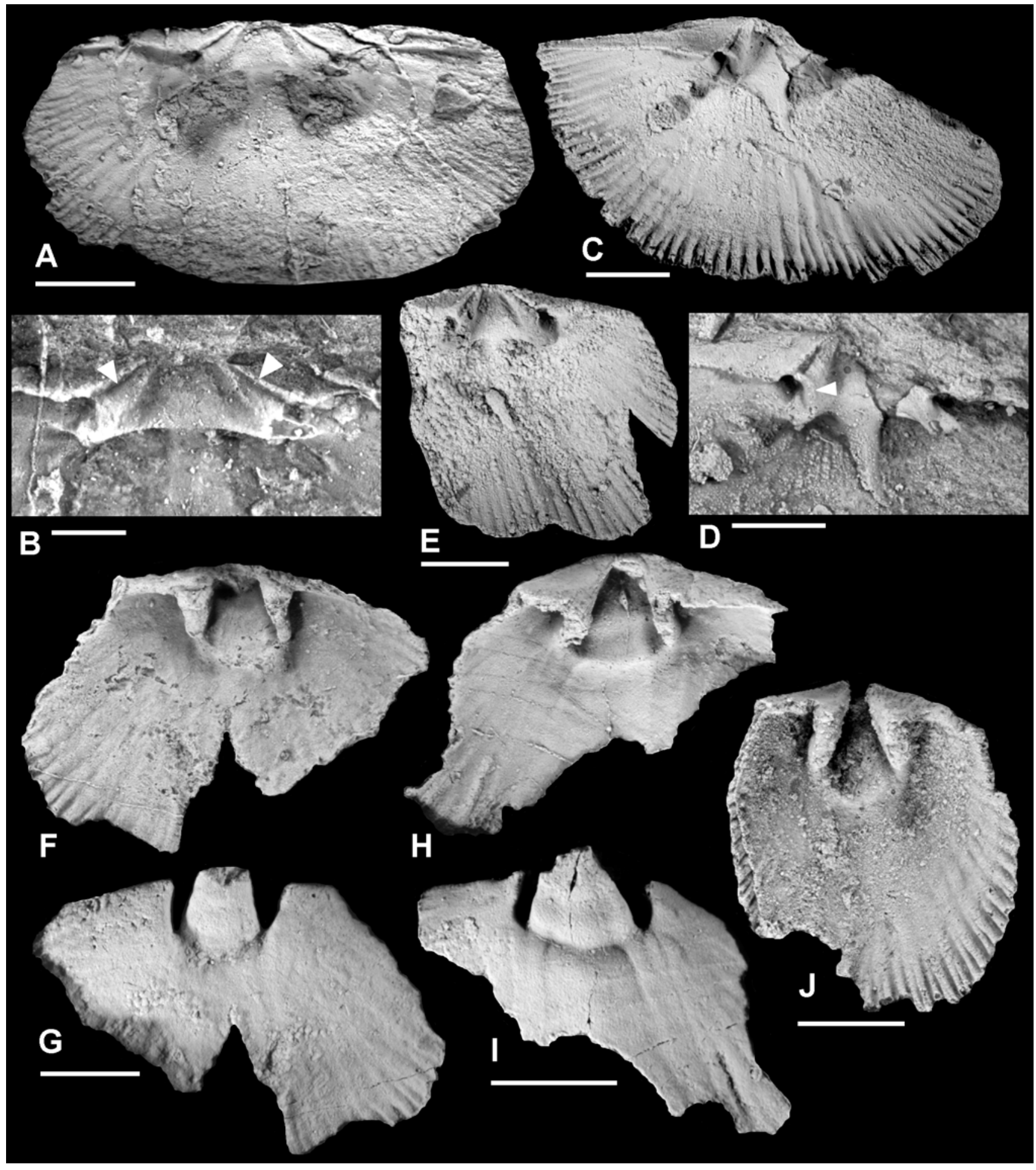

Fig. 4. Alocorthis psygmatelos n.gen. and n.sp. Scale bars $=2 \mathrm{~mm}$, unless otherwise stated; $(A, B)$ holotype, latex of dorsal valve interior, and detail of cardinalia $(B$, scale bar $=1 \mathrm{~mm})$; furrows extending along dorsal surface of brachiophores are arrowed in $B$; Note wide notothyrial platform lacking cardinal process, MTA/IV/4, AM F120719; $(C, D)$ latex of dorsal valve interior, and detail of cardinalia $(D$, scale bar $=1.5 \mathrm{~mm}$ ); fan-like termination of left brachiophore is arrowed in $D$, TAB1/55 m, AM F120720; $(E)$ latex of dorsal valve interior, TAB1/45 m, AM F120721; $(F, G)$ latex cast and original mould of ventral valve interior, MTA/0.2, AM F120722; $(H, I)$ latex cast and original mould of ventral valve interior, MTA/0.2, AM F120723; $(J)$ latex cast of ventral valve interior, TAB1/45 m, AM F120724.

Archaeorthis is also similar to Alocorthis in basic dimensions, but most species of this genus have the ventral muscle scar impressed on a well-developed callosity which extends forward as a wide median ridge (Ulrich \& Cooper, 1938, p. 92). Alocorthis psygmatelos does not possess this feature (Figs. 4F-J). Laurie (1987) described the species
Archaeorthis waratahensis from the Early Ordovician Digger Island Formation in south Gippsland, Victoria, that is characterized by the presence of a weakly developed callosity in the ventral valve (at least in early growth stages). This species can be discriminated from Alocorthis psygmatelos by its fascicostellate ornament, deep notothyrial 
cavity and well-developed dorsal sulcus in the dorsal valve. The brachiophores are also much simpler than those in Alocorthis psygmatelos (Figs. 4A-E).

Other nanorthid genera such as Cyrtonotella Schuchert \& Cooper, Diplonorthis Mitchell, Nicoloidea Zeng, Nothorthis Ulrich \& Cooper, Pleurorthis Cooper, Riograndella Kobayashi, Shoshonorthis Jaanusson \& Bassett and Xinanorthis Xu, Rong \& Liu can be distinguished from Alocorthis by a combination of features such as planoconvex to concavoconvex shape, presence of a welldeveloped cardinal process, weakly developed notothyrial platform or bilobed muscle field in the ventral valve (see Williams \& Harper, 2000, pp. 742-745).

Of the genera within the Eoorthidae that lack a cardinal process, Alocorthis is most similar to the type species of Robertorthis, R. holoubkovensis Havlíček (1977, pl. V, figs. $8-10,17)$, from the Early Ordovician (Tremadoc) of Bohemia. The internal morphology of the dorsal valve is almost identical in both species. The major differences are that the notothyrial platform of $R$. holoubkovensis is not supported by a median ridge, and the anterior extremities of the brachiophores in $R$. holoubkovensis bear fine ridges running parallel with the hinge line to define slit-like dental sockets. The ventral valve interiors of both taxa are also very similar, in that they possess a subtriangular muscle field which is raised above the valve floor and restricted to the delthyrial cavity.

Brahimorthis Havlíček from the Middle Cambrian of north Africa and Europe is also somewhat similar to Alocorthis in that it has ramicostellate ornament and lacks a cardinal process (see Havlíček, 1977, pl. II, figs. 15-19). Brahimorthis can be distinguished from Alocorthis by its lack of dental plates, and the presence of a raised transverse ridge in the delthyrial cavity (Williams \& Harper, 2000).

ACKNOWLEDGMENTS. The authors thank Ms Annie O'Connor for access to "Mount Arrowsmith" Station and for providing accommodation during fieldwork in February 2001. Dr Yong-Yi Zhen kindly identified the conodonts collected from the TAB 1 section and, in conjunction with Dr Ian Percival and Prof Barry Webby, provided access to an in press manuscript on the conodonts from Mount Arrowsmith. James Valentine kindly read an earlier draft of this manuscript. Drs Ian Percival and Des Strusz provided helpful reviews of the manuscript. Partial funding for this work was provided by a Betty Mayne Grant from the Linnean Society of New South Wales to JRP, and a Macquarie University Research Grant to GAB. Dean Oliver drafted Figs. 1-2 with characteristic accuracy and efficiency.

\section{References}

Benedetto, J.L., \& P.A. Carrasco, 2002. Tremadoc (earliest Ordovician) brachiopods from Purmamarca and the Sierra de Mojotoro, Cordillera Oriental of northwestern Argentina. Geobios 35: 647-661.

Brock, G.A., \& I.G. Percival, 2000. Cambrian faunas from Mount Arrowsmith, north-western New South Wales, Australia. Palaeontology Down Under 2000, Geological Society of Australia, Abstracts 61: 13.

Brown, I.A., 1948. Lower Ordovician brachiopods from Junee district, Tasmania. Journal of Paleontology 22: 35-39.

Crawford, A.J., B.P.J. Stevens \& M. Fanning, 1997. Geochemistry and tectonic setting of some Neoproterozoic and Early Cambrian volcanics in western New South Wales. Australian Journal of Earth Sciences 44: 831-852.

Etheridge, R. Jr., 1904. Trilobite remains collected in the Florentine Valley, west Tasmania. Records of the Australian Museum 5: 98-101.

Havlíček, V., 1977. Brachiopods of the order Orthida in Czechoslovakia. Rozpravy Ústredního Ústavu Geologického 44: 1-293.

Jaanusson, V., 1973. Ordovician articulate brachiopods. In Atlas of Palaeobiogeography, ed. A. Hallam, pp. 19-25. Amsterdam: Elsevier.

Jaanusson, V., \& M.G. Bassett, 1993. Orthambonites and related Ordovician brachiopod genera. Palaeontology 36: 21-63.

Laurie, J.R., 1980. Early Ordovician orthide brachiopods from southern Tasmania. Alcheringa 4: 11-23.

Laurie, J.R., 1987. Early Ordovician orthide brachiopods from the Digger Island Formation, Waratah Bay, Victoria. Memoirs of the Museum of Victoria 48: 101-106.

Laurie, J.R., 1991a. Ordovician brachiopod biostratigraphy of Tasmania. In Brachiopods through time, ed. D.I. MacKinnon, D.E. Lee \& J.D. Campbell, pp. 303-310. Rotterdam: A.A. Balkema.

Laurie, J.R., 1991b. Articulate brachiopods from the Ordovician and Lower Silurian of Tasmania. Memoir of the Association of Australasian Palaeontologists 11: 1-106.

Laurie, J.R., 1997. Early Ordovician fauna from the Gap Creek Formation, Canning Basin, Western Australia. AGSO Journal of Australian Geology \& Geophysics 16: 701-716.

Mills, K.J., 1992. Geological evolution of the Wonominta Block. In The Palaeozoic Eastern Margin of Gondwanaland: Tectonics of the Lachlan Fold Belt, southeastern Australia and Related Orogens, ed. C.L. Fergusson \& R.A. Glen, Tectonophysics 214: 57-68.

Paterson, J.R., 2001a. Early Ordovician Geology and Palaeontology of Mount Arrowsmith, northwestern New South Wales. Unpublished Hons thesis, Macquarie University, $123 \mathrm{pp}$.

Paterson, J.R., 2001b. First occurrence of Janospira from the Early Ordovician of Australia. Alcheringa 25: 129-130.

Paterson, J.R., 2002. Early Ordovician trilobites from Mt. Arrowsmith, northwestern N.S.W., Australia: Biostratigraphic and biogeographic implications. IPC2002, Geological Society of Australia, Abstracts 68: 128.

Paterson, J.R., in press. Palaeobiogeography of the Ordovician trilobite Prosopiscus, with a new species from western New South Wales, Australia. Alcheringa 27.

Percival, I.G., 1979a. Ordovician plectambonitacean brachiopods from New South Wales. Alcheringa 3: 91-116.

Percival, I.G., 1979b. Late Ordovician articulate brachiopods from Gunningbland, central western New South Wales. Proceedings of the Linnean Society of New South Wales 103: 175-187.

Percival, I.G., 1991. Late Ordovician articulate brachiopods from central New South Wales. Memoir of the Association of Australasian Palaeontologists 11: 107-177. 
Percival, I.G., B.D. Webby \& J. Pickett, 2001. Ordovician (Bendigonian, Darriwilian to Gisbornian) faunas from the northern Molong Volcanic Belt of central New South Wales. Alcheringa 25: 211-250.

Prendergast, K.L., 1935. Some Western Australian Upper Palaeozoic fossils. Journal of the Royal Society of Western Australia 21: 9-35.

Ulrich, E.O., \& G.A. Cooper, 1938. Ozarkian and Canadian Brachiopoda. Geological Society of America, Special Papers 13: $1-323$.

Wang Yu, 1955. New genera of brachiopods. Scientia Sinica 4(2): 327-357. [In Chinese].

Webby, B.D., 1978. History of the Ordovician continental platform shelf margin of Australia. Journal of the Geological Society of Australia 25: 41-63.

Webby, B.D., 1998. Steps towards a global standard for Ordovician stratigraphy. Newsletters on Stratigraphy 36(1): 1-33.

Webby, B.D., I.G. Percival, G.D. Edgecombe, R.A. Cooper, A.H.M. Vandenberg, J.W. Pickett, J. Pojeta Jr, G. Playford, T. Winchester-Seeto, G.C. Young, Y.Y. Zhen, R.S. Nicoll, J.R.P. Ross \& R. Schallreuter, 2000. Ordovician palaeobiogeography of Australasia. Memoir of the Association of Australasian Palaeontologists 23: 63-126.
Williams, A., S.J. Carlson, C.H.C. Bruton, L.E. Holmer \& L. Popov, 1996. A supra-ordinal classification of the Brachiopoda. Philosophical Transactions of the Royal Society, London B 351: 1171-1193.

Williams, A., \& D.A.T. Harper, 2000, Orthida. In Treatise on Invertebrate Palaeontology, Part H (revised), ed. R.L. Kaesler, vol. 3, pp. 714-782. Geological Society of America and University of Kansas Press.

Zhen, Y.-Y., I.G. Percival \& B.D. Webby, 2003. Early Ordovician conodonts from far western New South Wales, Australia. Records of the Australian Museum 55(2): 169-220.

http://www.amonline.net.au/pdt/publications/1383_complete.pdf · [from Nov 2003]

Manuscript received 29 November 2002, revised 15 March 2003 and accepted 2 April 2003.

Associate Editor: G.D. Edgecombe. 